\title{
Green Chemistry: The Economic Impact Perspective
}

\author{
Dini Hariyati Adam, Elvina, Mila Nirmala Sari Hasibuan, Rizki Syahputra, Laili Habibah Pasaribu, Suriyani
}

\begin{abstract}
Green chemistry is known as a study that aims to reduce or eliminate the adverse effects of the use of hazardous chemicals that can damage the environment and health. Environmental damage and poor health as caused by hazardous chemicals will affect the issuance of costs. This present study aims to discuss green chemistry and its impact on the economy through a literature review. This study is a review article that explains the concept of green chemistry and its impact on the economy. Based on the results of the study showed that the implementation of green chemistry will reduce the cost of recovery, prevention, and also reduce health costs. It is recommended that the firms in conducting manufacturing activities adopt green chemistry in their manufacturing activities.
\end{abstract}

Index Terms: Green Chemistry, Economic Impact

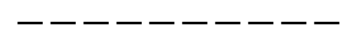

\section{INTRODUCTION}

Environmental problems have becomes very serious problems and need attention from the government. In 2018, the budget allocation for environmental protection is planned to be $\mathrm{Rp}$ 15,428.4 billion in Indonesia [1]. The diversity of industries that are growing is a demand for a more diverse lifestyle and consumption patterns of the people. In addition to increasing the amount of waste, the diversity of consumption patterns affects the composition of the material content of the waste becomes increasingly difficult to decompose naturally, pollute the environment and endanger human health [1]. The implementation of green chemistry is very important to reduce or prevent environmental damage. The lack of application of green chemistry will have an impact on environmental damage such as chemicals that are harmful to the environment and also to a humans health. Environmental damage or pollution caused by the lack of application of green chemistry will have an impact on the costs by the government or firms in overcoming environmental problems. The declining quality of the environment will also have an impact on economic growth and lead to various social conflicts that are sustainable and involve various elements of society, entrepreneurs and government.Green chemistry is known as a study that aims to reduce or eliminate the danger of adverse effects of chemicals on the environment, including humans. According to [2] Green chemistry is a very effective approach to prevent pollution because it can be used directly by scientists in the current situation.

- Dini Hariyati Adam, Universitas Labuhanbatu, Rantauprapat, Indonesia,

E-mail: dinihariyatiadam@gmail.com

- Elvina, Universitas Labuhanbatu, Rantauprapat, Indonesia, E-mail: elvinahrp19@gmail.com

- Mila Nirmalasari Hasibuan, Universitas Labuhanbatu, Rantauprapat, Indonesia, E-mail: milanirmalasari17@gmail.com

- Rizki Syahputra, Universitas Labuhanbatu, Rantauprapat, Indonesia, E-mail: rizki.pecintarasulullah@gmail.com

- Laili Habibah Pasaribu, Universitas Labuhanbatu, Rantauprapat, Indonesia,

E-mail: laili.habibah.pasaribu@gmail.com

- Suriyani, Universitas Labuhanbatu, Rantauprapat, Indonesia, E-mail: suryani.jahwa@yahoo.com
This concept focuses more on the perspective of a researcher to place environmental aspects on top priority. This area of research in the field of green chemistry includes the development of more environmentally friendly ways of synthesis, the use of renewable raw materials, designing green chemicals, and the use of biotechnology as an alternative in the industry. Green chemistry also aims to replace non-renewable raw materials with renewable with the aim of avoiding negative effects on health [3]. The same opinion was expressed by [4] said that green chemistry reduces or eliminates the need for and generation of hazardous materials during the manufacture, design, and application of chemistry. This present study aims to explore the economic impact of the implementation of green chemistry.

\section{METHODOLOGY}

This research is a review article describing green chemistry and its impact on the economy. According to [5] literature review is a method of collecting data in a way looking for information through books, newspapers, magazines, and other literature. The review articles in the research sourced from several journal studies related to green chemistry and its economic impact.

\section{FINDING}

\subsection{The Concept of Green Chemistry}

Green chemistry is a new paradigm providing solutions for contemporary, ecological, and sustainable challenges. The term green chemistry is often used to conserve resources and the environment [6] and also redesign of chemical products to eliminate toxicological and environmental impact [7]. Green chemistry strives to minimize waste production, to promote the use of renewable and recycled resources, and to achieve the highest possible energy efficiency[8]. In paper [9] cited that green chemistry often described as an 'innovative, nonregulatory, economically driven approach toward sustainability. In paper [10] cited that green chemistry provides an excellent framework for creating systems that are consistent with the circular economy (consider especially the principles of waste prevention, optimize atom economy, use harmless components, the using of renewable raw materials, and also design for degradation). The concern of green chemistry is to eliminate or minimize the generation of toxic waste has become greater than treating the waste already generated[11]. 
According to [12], said that there are twelve principles of green chemistry namely :

1. Avoid pollution: chemical syntheses, processes, and reactors need to be designed to avoid dirt and contamination;

2. Design safer chemical products: this principles emphasize effective products that use less toxic than comparable materials:

3. Produce less hazardous substances: create and use substances that pose no risk to humans and the environment;

4. Use renewable raw materials as much as possible;

5. Use of catalysts instead of stoichiometric reagents by minimization of the reaction partners;

6. Avoid unnecessary intermediate steps in chemical processes;

7. Maximize the atom efficiency: design syntheses and reactions so that no, or only a few atoms or molecules of the initial reagents remain, or, so that no unwanted dangerous substances remain;

8. Use safe solvents and safe reaction conditions: if possible, avoid the use of adjuvants;

9. Increase energy efficiency: if possible manage reactions and processes at room temperature;

10. Produce chemicals and side products: these can be degraded without harming the environment;

11. Control all operations by real time management to prevent pollution and contamination, which will help to avoid waste;

12. Minimize the risk of accidents

\subsection{Economic Impact}

Green chemistry has a role not only to protect the environment issue by preventing pollution before its creation; green chemistry is also a way of the firm to increase efficiency and reduce the costs of production, an opportunity for businesses to lighten their environmental burdens and make money [8]. The same opinion also states that the application of green chemistry can improve economic performance [3]. In paper [11] said that the benefits of economic on the implementation of green chemistry such as the less need for investment in waste storage and treatment by the firms, as well as compensation payments for environmental damage. Recycling is one of the concepts in green chemistry and very fundamental in promoting a circular economy, which is a new paradigm of sustainability that is able to reduce environmental implications, and in creating new business opportunities[13]. Environmental chemistry is not only important to humans and the environment but is also crucial for business and economy. It helps in finding methods and techniques to speed up the chemical reactions using small amounts of reactants to deliver the same results and the same price of the product. It also helps in reducing the number of synthetic steps that enable increased production, increase in the plant capacity while saving energy and water consumption. Using fewer chemicals for manufacturing the products results in reduced waste which results in reduced cost for disposing of chemical waste and toxic waste treatments [14] The economic benefits of green chemistry are central drivers in its advancement. The industry is adopting green chemistry methodologies because they improve the corporate bottom line. A wide array of operating costs is decreased through the use of green chemistry[2]. Other economic benefits can be obtained from the application of green chemistry, as stated by [11] that the economic benefit of green chemistry such as the less need for investment in waste storage and treatment, as well as compensation payments for environmental damage. [11], and also economic efficiency [15].

If the company does not apply green chemistry, it will cause environmental pollution. According to [16] some of the losses caused by environmental pollution are as follows:

1. Disaster Relief Cost

When environmental pollution and / or damage happens, immediate action needs to be taken to tackle environmental pollution and / or damage that occurs so that environmental pollution and / or damage can be stopped and not become worse. This action can be carried out by business actors and / or activities, and / or by the government.

2. Recovery Cost

The environment which is polluted and / or damaged must be restored and as far back as possible, before pollution and / or environmental damage occurs. This action to restore the environment applies to the public environment which is the right and authority of the government and the community that includes the rights and authority of individuals and groups of people. However, not all environments can be returned to conditions such as before pollution and / or environmental damage occurred, however the party responsible for a business and / or activity and / or individual that causes pollution and / or environmental damage is obliged to restore environmental conditions. With the restoration of environmental conditions, it is expected that environmental functions that were present before the damage could return to normal. But it must be realized that there are various kinds of ecosystems, and each ecosystem has different benefits and functions, so the recovery effort also requires different technologies. Efforts to restore the condition and function of the environment require the cost of environmental recovery.

3. Ecosystem loss

When the environment becomes polluted and / or damaged, various impacts will emerge as a result of pollution and / or damage to the ecosystem. Pollution and / or damage to the environment includes the public (government) environment. All impacts of pollution and / or environmental damage must be calculated for its economic value so that a complete environmental loss value is obtained. For example if there is an oil leak from a tanker, the marine ecosystem becomes polluted. The next impact can be damage to coral reefs, damage to mangrove forests or damage to seagrass beds, so that the productivity of all types of these ecosystems in producing fish is reduced.

Generating of environmental pollution in modern societies is unavoidable and industrial nations will always produce a certain level of pollutants. Some of the pollutants, even potentially very harmful to the environment are at the same time very beneficial for individuals and communities. The good examples are the pesticides, which besides their potential harmful effects, at the same time, have greatly contributed to the increase of overall food production in the world; the pharmaceuticals, which require potentially dangerous organic chemicals for their manufacture, at the same time considerably have extended human lives; plastics, one of the 
main environmental pollutants all over the world, are used in all aspects of medical and domestic life, etc. What modern societies need to do is to find an optimal balance between the attempts to minimize the costs and to increase profits in manufacturing numerous consumer and industrial goods and requesting industries and individuals to reduce pollution in their operations[17]. In [18] also said that the benefit of green chemistry namely increased consumer sales by earning and displaying a safer-product label (e.g., Safer Choice labeling) and also Improved competitiveness of chemical manufacturers and their customers. In paper [11] that it is possible to predict some of the benefits of economically generated by the implementation of green chemistry in industrial chemical processes, such as the less need for investment in waste storage and treatment, as well as compensation payments for environmental damage.

\section{CONCLUSION}

The review results show that there are economic benefits obtained by the implementation of green chemistry such as reducing disaster relief costs and recovery costs, the less need for investment in waste storage and treatment, otherwise, if green chemistry is not applied it will result in losses such as increased recovery costs as an impact environmental damage.

\section{REFERENCES}

[1] Badan Pusat Statistik, "Statistik Lingkungan Hidup Indonesia (SLHI) 2018," Badan Pus. Stat. Indones., pp. 1-43, 2018.

[2] S. K. Sharma, A. Chaudhary, and R. V. Singh, "Gray chemistry verses green chemistry: Challenges and opportunities," Rasayan J. Chem., vol. 1, no. 1, pp. 68-92, 2008.

[3] R. R. S. Saini and U. U. R. Singh, "Green chemistry: Environment, economics, and competitiveness," Corp. Environ. Strateg., vol. 9, no. 3, pp. 259-266, 2002.

[4] K. Thomas, J. Tickner, and K. Zarker, Growing the Green Economy Through Green Chemistry and Design for the Environment. 2009.

[5] A. Suharsimi, Prosedur Penelitian Suatu Pendekatan Praktik. Jakarta: Penerbit Rineka Cipta., 2013.

[6] N. O. Bedenik and N. Zidak, "Green Economy Supported By Green Chemistry," Eurasian J. Bus. Manag., vol. 7, no. 2, pp. 49-57, 2019.

[7] N. Winterton, "Green chemistry: deliverance or distraction?," Clean Technol. Environ. Policy, vol. 18, no. 4, pp. 991-1001, 2016.

[8] A. E. Marteel-Parris and M. A. Abraham, Green Chemistry and Engineering. New Jersey: John Wiley \& Sons, Inc, 2014.

[9] V. R. Veleva and B. W. Cue, "The role of drivers, barriers, and opportunities of green chemistry adoption in the major world markets," Curr. Opin. Green Sustain. Chem., vol. 19, pp. 30-36, 2019.

[10] M. Linder, "Ripe for disruption: Reimagining the role of green chemistry in a circular economy," Green Chem. Lett. Rev., vol. 10, no. 4, pp. 428-435, 2017.

[11] B. A. de Marco, B. S. Rechelo, E. G. Tótoli, A. C. Kogawa, and H. R. N. Salgado, "Evolution of green chemistry and its multidimensional impacts: A review," Saudi Pharm. J., vol. 27, no. 1, pp. 1-8, 2019.

[12] P. T. Anastas and J. C. Warner, Green Chemistry,
Theory and Practice. Oxford, UK: Oxford University Press, 1998.

[13] R. Cucciniello and D. Cespi, "Recycling within the chemical industry: The circular economy era," Recycling, vol. 3, no. 2, pp. 6-9, 2018.

[14] "Retrieved February, 2nd 2020 from http://www.incaweb.org/." .

[15] R. Shanghi, The Need For Green Chemistry" :Environt Friendly Alternative. New Delhi: Naroso Publishing House, 2003.

[16] "Peraturan Menteri Lingkungan Hidup Republik Indonesia Nomor 7 Tahun 2014 Tentang Kerugian Lingkungan Hidup Akibat Pencemaran Dan/Atau Kerusakan Lingkungan Hidup."

[17] B. Zvonko, C. Marijana, and S. Ivan, "Assessment of the Socio-economic Impact of the Chemicals Environmental Contamination," Int. Rev., no. 1-2, pp. 113-118, 2015.

[18] "Retrieved February, 2nd 2020 from https://www.epa.gov/greenchemistry/benefits-greenchemistry." . 